Vol. 30, julho 2014, http://dx.doi.org/10.5380/dma.v30i0.34198

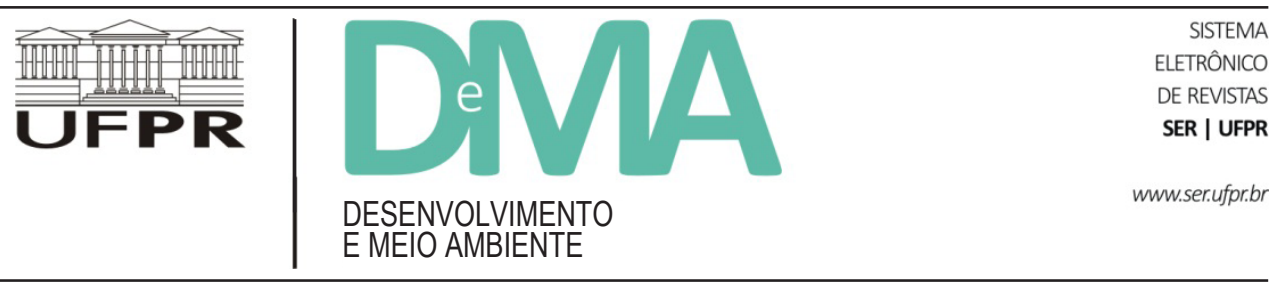

\title{
Utilização de ferramentas livres para gestão territorial do nexo água e energia
}

\section{Using Free Tools for Territorial Management of Water and Energy Nexus}

\author{
Renata Saviato DIAS ${ }^{1}$, Andressa Crystina Coutinho da SILVA², Cristiane FRACARO ${ }^{3}$, Cícero Jaime BLEY \\ $\mathrm{JUNIOR}^{4}$ \\ ${ }^{1}$ Engenheira Sanitarista e Ambiental (UFSC). Analista Ambiental do Centro Internacional de Hidroinformática (CIH), Parque Tecnológico de \\ Itaipu (FPTI). E-mail: renata.dias@pti.org.br \\ ${ }^{2}$ Engenheira Ambiental (UNIAMERICA). Engenheira Ambiental do Centro Internacional de Hidroinformática (CIH), Parque Tecnológico de \\ Itaipu (FPTI). E-mail: andressa@pti.org.br \\ ${ }^{3}$ Tecnóloga Ambiental (UTFPR). Engenheira Ambiental do Centro Internacional de Hidroinformática (CIH), Parque Tecnológico de Itaipu \\ (FPTI). E-mail: cristiane@pti.org.br
}

${ }^{4}$ Engenharia Agronômica (UFPR). Assessoria de Energias Renováveis, Itaipu Binacional. E-mail: cbley@itaipu.gov.br

Artigo: Recebido em: 3 de novembro de 2013; Versão final aceita em: 16 de junho de 2014.

RESUMO A situação das águas e sua gestão são circunstâncias essenciais para o desenvolvimento econômico, sendo então fundamental a promoção de soluções e ferramentas de auxílio à gestão. Tais ferramentas caracterizam o território e qualificam os entes água e energia a fim de que se concilie esse importante nexo, envolvendo conhecimentos, tecnologia, política e aspectos sociais e econômicos. O Centro Internacional de Hidroinformática é referência em informática aplicada à gestão de recursos hídricos, trabalhando a gestão territorial com tecnologias livres de geoprocessamento e SIG. O CIH realiza o registro de informação em bases de dados geográficas e os apresenta em mapas interativos por meio de Sistemas de Informações Geográficas - SIG - na web, como demonstrado para a bacia hidrográfica do São Francisco Verdadeiro, case do Centro. O desenvolvimento de sistemas de informação geográfica aplicada à gestão territorial utilizando geotecnologias livres possibilita soluções de manipulação dos dados geográficos para auxílio na tomada de decisão, com o benefício da replicação em qualquer realidade por seu uso livre e universal.

Palavras-chave: água; gestão territorial; energia.

ABSTRACT The understanding of the situation and water management is an essential condition for economic development, so it is vital the promotion of solutions and support to management tools. Such tools characterize the territory and qualify the entities water and energy to reconcile this important nexus, involving knowledge, technology, politics and social and economic aspects. The Hydroinformatics International Centre is reference in Hydroinformatics applied to water resources management, working the territorial management with technologies free 
from geoprocessing and GIS. CIH keeps records of information in geographic databases and displays it on interactive maps by means of the web Geographic Information Systems, like demonstrated for the watershed of the San Francisco Real, Center's case. The development of geographic information systems applied to water resources management using geo solutions enables free manipulation of geographic data to aid in decision making, with the benefit of replication in any reality by their free and universal use.

Keywords: water; territory management; energy.

\section{Introdução}

Mediante o desafio que a humanidade enfrenta para o encaminhamento de resoluções para as tensões relativas à sustentabilidade dos recursos hídricos e ao desenvolvimento humano, é impossível prever o futuro sem a disponibilidade de água e de energia e a sustentabilidade sem a aplicação de uma como fonte da outra. Neste contexto, é fundamental promover soluções e ferramentas de gestão territorial que identifiquem este caos no território e qualifiquem os entes água e energia para conciliar esse importante nexo.

$\mathrm{O}$ citado território pode ser compreendido como um recorte administrativo ou uma área que engloba amplamente toda uma região ou somente uma porção desta. Constata-se que o território abordado em estudos ou projetos não se limita ao tamanho, contudo, incorpora à sua dimensão todo o conjunto de relações contidas e relacionadas com sua diversidade e potenciais socioeconômicos, ambientais e as possíveis alternativas de atuação para a transformação e o desenvolvimento local (Martins et al., 2010). Estas relações ocorrentes no âmbito territorial requerem, na medida de seus desenvolvimentos, um planejamento com o propósito de ordenar as ações e resguardar a disponibilidade dos recursos naturais.

A evolução tecnológica, científica e econômica global coopera extensivamente com o avanço da exploração dos recursos naturais e, à vista disso, o planejamento territorial é requisitado com premência, abrangendo as temáticas socioeconômicas e as ambientais, considerando as vulnerabilidades e potencialidades do meio. Conforme Donha et al. (2006), para se determinar as potencialidades dos recursos naturais, é necessário conhecer dados dos solos, relevo, geologia, água, clima e vegetação: componentes de suporte à vida; seguida deste conhecimento, pode-se realizar a análise de fragilidade ambiental envolvendo as interferências antrópicas.
Referenciando a Lei brasileira $\mathrm{n}^{\circ}$ 9.433/97 - Lei das Águas, a gestão dos recursos hídricos deve reunir uma série de outras gestões, devido às inter-relações existentes entre todos os setores envolvidos com os recursos hídricos. Isto posto, nota-se que ambas as gestões citadas são incorporadas uma à outra, sendo impossível um manejo eficiente dos recursos hídricos sem o foco também no território.

A preservação dos recursos hídricos é primordial a fim de que se mantenha um montante com qualidade para consumo humano, agricultura e indústria e para suprir as demandas naturais dos ecossistemas. Isto é possível pela adaptação das atividades antrópicas aos limites da capacidade da natureza e o discernimento de quantia d'água utilizada por setores produtivos (Rauber \& Oliveira, 2008).

Para a compreensão do panorama atual dos recursos hídricos, é fundamental determinar a disponibilidade hídrica em função da sua qualidade da água, das demandas e usos múltiplos e do balanço hídrico (ANA, 2012). Conclusivamente, essa é a análise dos recursos hídricos, pois abrange eventos hidrológicos extremos, setores usuários de água, a relação oferta-demanda e apresenta a situação ambiental das águas, permitindo a avaliação da gestão.

A compreensão da situação e a gestão das águas são circunstâncias essenciais para o desenvolvimento econômico, principalmente em países que têm sua matriz energética focada na hidroeletricidade, como é o caso do Brasil; ademais, a água é matéria-prima fundamental em diversos processos produtivos. A segurança dos recursos hídricos é um aspecto suplementar a ser considerado no planejamento dos futuros sistemas energéticos, segundo Rio Carrillo e Frei (2009). Tais fontes podem ser renováveis ou não, sendo que as fósseis tendem a um limite de oferta (Moura, 2010). Diferentemente do caso da hidroelétrica, onde, desde que os recursos hídricos sejam preservados e a disponibilidade mantida, haverá geração de energia. 


\subsection{Conjuntura dos recursos hídricos e sua gestão}

Sabe-se que o Brasil possui excelente disponibilidade de recursos hídricos, contando com $12 \%$ de toda a água doce do planeta ou a vazão de $180 \mathrm{mil} \mathrm{m} 3 / \mathrm{s}$ disponível em rios (Rauber \& Oliveira, 2008). A disponibilidade de água por pessoa no Brasil é de $32 \mathrm{mil} \mathrm{m}^{3} /$ hab./ano, 19 vezes superior ao mínimo estabelecido pela Organização das Nações Unidas. Apesar da favorável conjuntura, existe uma distribuição espacial desigual de recursos hídricos no território brasileiro (Mendonça \& Leitão, 2008). Cerca de $80 \%$ do montante estão concentrados na região Amazônica (ANA, 2012), onde se encontram o reduzido contingente populacional e menores demandas do recurso.

As demandas consuntivas são aquelas que captam determinado volume de água para o processo produtivo e parte desta quantia não retorna ao corpo hídrico. Uma estimativa das demandas consuntivas em 2010, de acordo com ANA (2012), retrata que 54\% da vazão foi retirada pela irrigação, seguida pelos setores urbano e industrial com, respectivamente, $22 \%$ e $17 \%$. A vazão para consumo animal fica em $6 \%$ e rural, em $1 \%$. Tais valores ressaltam causas de vários problemas ambientais, como a poluição gerada pelos resíduos agrotóxicos utilizados da agricultura e pelos lançamentos de efluentes industriais em corpos hídricos e emissões atmosféricas. Associado a estes, estão os ascendentes problemas da saúde pública devido ao agravamento da qualidade das águas para consumo humano.

Os padrões de qualidade da água são estabelecidos pela resolução do CONAMA n. ${ }^{\circ} 357$, onde são dispostos os enquadramentos e classificações de corpos hídricos e padrões de lançamento de efluentes. Porém, tais índices permitem a avaliação restrita das variáveis físico-químicas e bacteriológicas, consistindo na coleta de amostras em campo e posterior análise em laboratório. Apesar de amplamente utilizada, essa metodologia apresenta desvantagens, principalmente quando se trata da água de rios.

Os cursos d'água são ecossistemas dinâmicos e sua representação por meio de coletas nem sempre os reflete verdadeiramente. Desta forma, as amostras de água não periódicas são como fotografias da qualidade do rio, retratando apenas o momento da coleta (CIH, 2010). Para preencher esta lacuna, sugere-se o monitoramento biológico ou biomonitoramento, que funciona como um histórico de longa-metragem do corpo hídrico. O conceito baseia-se nas reações provindas dos organismos em relação ao meio onde habitam, pois a biota aquática é capaz de responder diferentemente a distúrbios naturais ou antropogênicos (Buss et al., 2008).

A percepção de que informações sobre organismos aquáticos podem ser utilizadas como indicadores teve reflexo na legislação brasileira onde, na Resolução CONAMA 357/05, foi citado o uso de instrumentos de avaliação biológica: “a qualidade dos ambientes aquáticos poderá ser avaliada por indicadores biológicos quando apropriado, utilizando-se organismos e/ou comunidades aquáticas". Entretanto, ainda não há, nas legislações brasileiras, normas para padronização dos métodos a serem usados no monitoramento biológico e sua gestão.

É de grande importância a integração dos resultados físico-químicos e bacteriológicos com os biológicos dos ecossistemas aquáticos, pois assim aperfeiçoam-se os meios de detecção de impactos ambientais. Além disso, analisar a atuação de poluentes em organismos é moderadamente simples, pois estes são indicadores visíveis a olho nu.

No contexto de gestão integrada e participativa, descrita na Lei $n^{\circ}$ 9.433/97 e outras, são definidos os planos para a gestão da bacia hidrográfica que buscam, além da descentralização e da participação da sociedade civil, uma legitimidade para as ações a serem estruturadas (Buss et al., 2008). Para estabelecimento da gestão dos recursos hídricos, segundo o modelo participativo acima definido, são salientadas fases essenciais, como: criação do arcabouço legal e da estrutura institucional; elaboração de diagnóstico dinâmico; definição de critérios de controle; composição de coleta de contribuições dos usuários; sistema de informações e monitoramento continuado; divulgação e educação ambiental (Leal, 1998).

Para Peixinho (2010), há dois desafios relevantes a serem solucionados pelo Brasil em relação aos recursos hídricos: a escassez de água em algumas regiões e a degradação da qualidade das águas, tema já apresentado. Porém, sabe-se da existência de outros problemas a se- 
rem enfrentados, como, por exemplo, a altíssima quantia de água demandada para irrigação, com $46 \%$ do total de recursos hídricos captados (Rauber \& Oliveira, 2008), e a falta de saneamento básico onde, segundo o IBGE (2008), mais da metade dos domicílios brasileiros não possuem rede coletora de esgoto. Contudo, em comparação entre 2000 e 2008, houve um aumento de cerca de $8 \%$ da rede coletora de esgoto e um acréscimo de quase $10 \%$ no tratamento deste esgoto coletado em relação ao produzido (ANA, 2012). Tais dados exemplificam a atuação da gestão dos recursos hídricos atualmente.

A gestão dos recursos hídricos deve abordar, além das discutidas demandas consuntivas e qualidade da água, o balanço hídrico da bacia norteando a gestão. $\mathrm{O}$ balanço quantitativo relaciona a demanda com a disponibilidade e transparece as regiões de estresse hídrico, como o semiárido brasileiro, e o balanço qualitativo diagnostica a capacidade de depuração do corpo hídrico em relação à carga poluente lançada em seu curso (Silveira et al., 2003). Ao somarem-se os resultados de ambos os balanços, é possível caracterizar a situação da bacia hidrográfica e assim manejá-la de forma eficiente quanto às suas capacidades e suas vulnerabilidades, como mudanças climáticas e eventos críticos (Mendonça \& Leitão, 2008).

\subsection{Matriz Energética Brasileira}

Com o desenvolvimento temporal econômico, o ascendente consumo de energia foi tanto que se tornaram necessárias outras fontes de energia para seu abastecimento. Atualmente, o modelo de produção e consumo de energia é atendido, em maior parte, por fontes fósseis, gerando emissões de poluentes como os gases de efeito estufa, que expõem o planeta ao risco. É preciso uma alteração nesses padrões que incentive fontes renováveis e, nesse sentido, o Brasil apresenta uma condição bastante favorável em relação ao resto do mundo (Goldemberg \& Lucon, 2007).

Para Bronzatti e Iarozinski Neto (2008), em 2006, o país transformou a balança de importação de petróleo e atualmente tem premissas para tornar-se um grande produtor de petróleo e gás natural. Os autores citam também que o período de desenvolvimento econômico forte em que o Brasil vive acarreta mudanças na sua estrutura econômica e em sua produção de energia.

Além do amplo potencial para produção de combustíveis fósseis, o Brasil compõe o grupo de nações onde a produção de eletricidade é originária, em grande porção, de usinas hidroelétricas. A Figura 1 apresenta o balanço da matriz energética brasileira para 2011 e 2012.

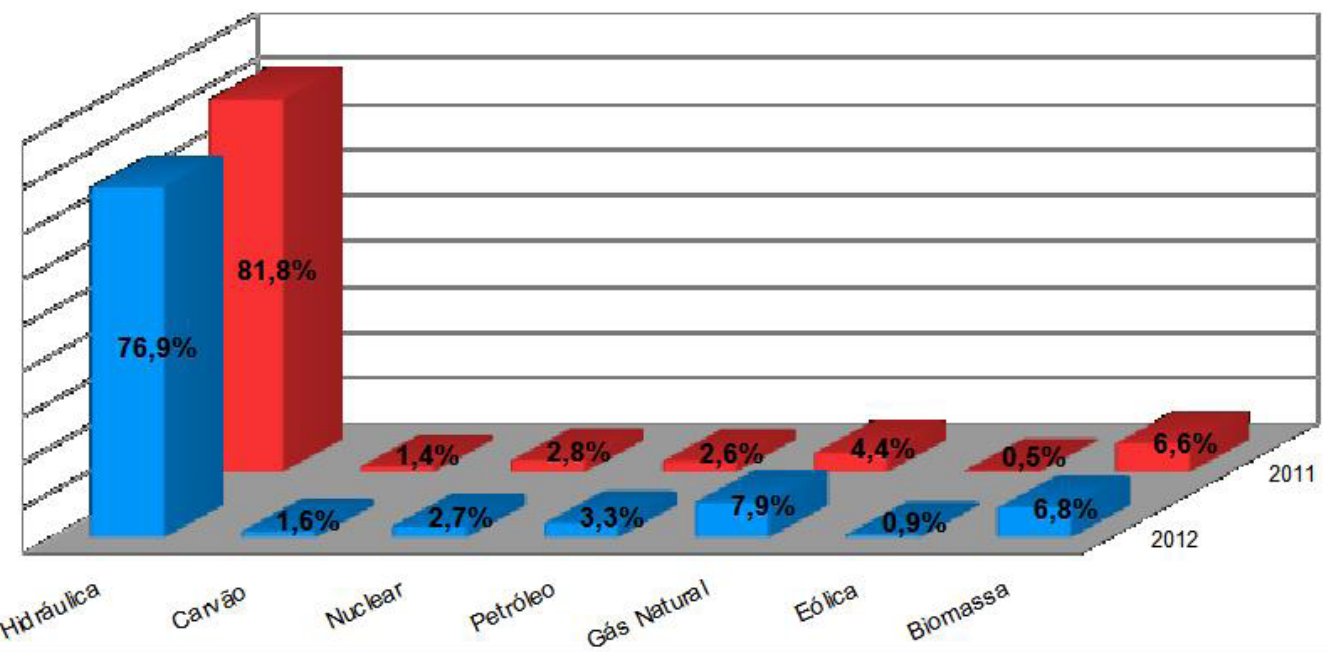

FIGURA 1 - Balanço da Matriz Energética Brasileira nos anos de 2011 e 2012.

FONTE: Adaptado do Ministério de Minas e Energia, 2013. 
Pode-se conferir o aumento de $1.835 \mathrm{MW}$ na potência instalada do parque hidrelétrico, apesar da oferta de energia hidráulica ter reduzido em 1,9\% devido às condições hidrológicas ocorridas em 2012, especialmente na segunda metade do ano, conforme Figura 1. A menor oferta hídrica justifica então a diminuição no setor de energias renováveis na matriz elétrica, de $88,9 \%$ em 2011 para 84,5\% neste ano (MME, 2013). Atenta-se aqui a grande dependência atual e futura do setor em relação ao aproveitamento hídrico disponível no país, demonstrando a necessidade da gestão dos recursos hídricos.

O Brasil possui cerca de $43 \%$ da sua Oferta Interna de Energia (OIE) abastecida por fontes renováveis (Figura 2), estando em posição apreciável em comparação com a média mundial de 14\% e dos países desenvolvidos, de apenas 6\% (MME, 2012). Para compor esse novo quadro de matriz energética, existe um enorme potencial nas fontes renováveis, como as energias solar e eólica que, segundo MME (2013), atingiu potência eólica de $1.894 \mathrm{MW}$, o que propiciou dobrar a fatia desta fonte na matriz elétrica nacional.

No aproveitamento comercial eólico, são previstos potenciais no Nordeste, Sudeste e Sul do país e, para a energia solar, em todo o território brasileiro, porém são necessários ainda investimentos e pesquisas a fim de baratear seus custos (Bronzatti \& Iarozinski Neto, 2008).

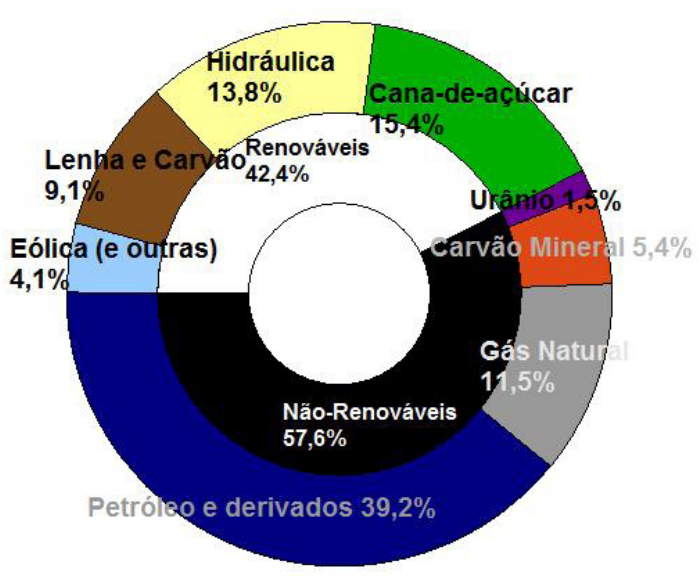

FIGURA 2 - Oferta Interna de Energia renovável e não renovável no Brasil em 2012.

FONTE: Adaptado do Ministério de Minas e Energia, 2013.
Além destas fontes, o Brasil também possui potencial de exploração de urânio para utilização em usinas nucleares, contribuindo na oferta interna de energia com 1,5\% (Figura 2), sendo uma energia limpa, porém não renovável. Ainda assim, os procedimentos são mais complexos devido às questões ambientais, aos altos custos de investimento e à importação de tecnologia.

O setor com maior consumo de energia é o industrial $(35,1 \%)$, seguido pelos transportes $(31,3 \%)$ e residências $(9,4 \%)$. No balanço do ano de 2012 , notou-se o aumento do consumo final de eletricidade de 3,8\%, requerido pelas famílias e pelo setor de serviços, sendo atendidos com aumento da geração térmica convencional, especialmente das usinas movidas a gás natural, cuja participação na matriz cresceu de $4,4 \%$ para $7,9 \%$ (MME, 2013).

\subsection{Tríades temáticas}

Citando Moura (2010), a água é recurso base demandado para as diferentes fases do suprimento de energia, nas quais está inclusa a extração de energéticos, como: mineração, refino de petróleo, gás natural, beneficiamento de carvão e urânio, liquefação de gás natural e gaseificação de carvão, sequestro de carbono; e também na geração de eletricidade, como em de usinas térmicas movidas a carvão, gás natural, solar, biomassa e termonucleares.

A relação entre água e energia se apresenta de várias formas e, principalmente, em tríades como água-abastecimento urbano-energia, água-alimento-energia, água-biomassa-energia, água-gestão territorial-energia. Isto devido a uma interdependência existente entre ambas, que se torna mais intensa por interferências de crescimento econômico, aumento demográfico, crise energética e os impactos ambientais, como as alterações climáticas.

Os sistemas de abastecimento de água possuem gastos energéticos significativos, considerando que cerca de $80 \%$ de seus custos totais estão relacionados com a energia necessária em seus processos. E, em casos de extração de águas subterrâneas, é acrescido ao consumo total cerca de $30 \%$ devido ao sistema de bombeamento necessário (Gregório \& Martins, 2011). Segundo Moura 


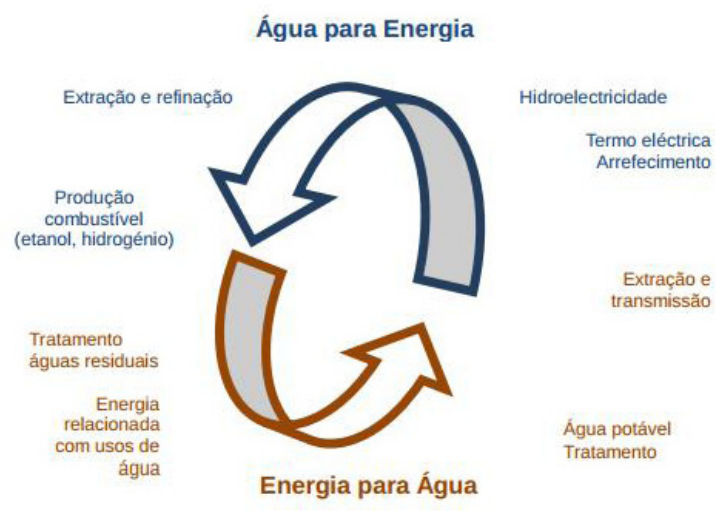

FIGURA 3 - Atividades atuantes no contexto do nexo água e energia.

FONTE: World Business Council for Sustainable Development WBCSD, 2009.

(2010), os dispêndios com energia elétrica são a segunda maior receita desses sistemas, contudo, existem duas perspectivas importantes: a primeira debate o consumo de energia para o abastecimento urbano e agrícola de água e a segunda, a utilização dos recursos hídricos para a geração de energia.

Além do abastecimento, os sistemas de tratamento de águas residuárias são consumidores tão importantes quanto. Gregório e Martins (2011) relatam que a medida desta importância é relacionada com a escassez de água e com a intensificação de secas e falta de água, onde os efluentes líquidos, após tratamento adequado, tornam-se fontes potenciais de água. Entretanto, este tratamento demanda alto consumo de energia elétrica.

Outro fator importante é o aumento da utilização da água pelo setor energético, como na produção de bioenergia por consequência do processamento da biomassa e do consumo de água para o cultivo das culturas. A "pegada hídrica" para biomassa é de $72 \mathrm{~m} 3 / \mathrm{GJ}$, já para energia hidrelétrica e petróleo fica com 22 e 1,1 respectivamente (Moura, 2010).

De fato, a utilização da biomassa para geração elétrica é opção de fonte renovável e pode contribuir com o desenvolvimento sustentável, pois possibilita a substituição, em parte, dos combustíveis fósseis. Além disso, Berndes (2002) afirma que alguns métodos de produção de energia utilizando a biomassa apresentam emissões negativas de gases do efeito estufa. Porém, a expansão desacompanhada dos biocombustíveis pode acrescentar pressão sobre os recursos hídricos, devido à já comentada demanda necessária de água para o cultivo e processamento da biomassa.

A relação entre água, alimento e energia advém do crescimento populacional, que carece de maior quantidade de alimento. Assim, requer-se maior quantidade possível de solo para agricultura, disparando o uso da irrigação a fim de suprir a agropecuária e a demanda do aumento demográfico. O uso da irrigação de forma ineficiente e em excesso tem por inferência o desperdício de água e energia utilizadas em um bombeamento desnecessário, desconsiderando o manejo racional da irrigação, que se baseia na aplicação de quantia de água suficiente nas plantas (Lima et al., 1999).

Segundo estudo realizado pela Companhia Energética de Minas Gerais - CEMIG, caso se racionalizasse a irrigação, cerca de $20 \%$ da água e $30 \%$ da energia consumidas seriam poupadas, sendo $20 \%$ da energia economizada devido à aplicação desnecessária da água e $10 \%$ devido ao redimensionamento e otimização dos equipamentos utilizados para a irrigação (CEMIG, 1993).

Além deste gasto excedente, a aplicação da água para agricultura concorre com o uso para geração de eletricidade em casos de a tomada de água ser executada à montante de uma usina hidrelétrica. Assim sendo, a eficiência na gestão dos recursos hídricos pleiteia que todas as viabilidades de aproveitamento sejam analisadas concomitantemente, sendo incomuns casos em que o uso pode ser visto isoladamente (Lima et al., 1999).

Segundo Peixinho (2010), o modelo adequado para a gestão dos recursos hídricos deve considerar a bacia hidrográfica como unidade de gestão territorial, em razão das inter-relações de dependência entre os fenômenos físicos advindos em sua área. Concordando, a Lei Federal $n^{\circ} 9.433 / 97$, sobre gestão dos recursos hídricos, cita que

\footnotetext{
${ }^{1}$ A pegada hídrica é definida como o volume de água total usado durante a produção e consumo de bens e serviços, bem como o consumo direto e indireto no processo de produção.
} 
o planejamento deve ser realizado no território da bacia hidrográfica.

O manejo dos recursos hídricos deve ser realizado amplamente, considerando as ações existentes no território, a fim de compreender e ponderar as interações que ocorrem entre o nexo água e energia. Como ferramenta que possibilita tal manejo, apresenta-se a gestão territorial que, com foco delimitado em bacias hidrográficas, é capaz de integrar informações pertinentes ao planejamento integrado e diagnóstico da área. Este gerenciamento é apresentado, neste artigo, para a bacia hidrográfica do rio São Francisco Verdadeiro, case do Centro Internacional de Hidroinformática, e os Sistemas de Informações Geográficas - SIG - que envolvem os temas da bacia.

\section{Gestão territorial e o nexo água-energia}

Concordando com Guivant e Jacobi (2003), de maneira geral, é nos grandes aglomerados de cidades que questões urbanas mais gerais e, especificamente, de gerenciamento de recursos hídricos se tornam mais complexas. O ritmo ainda forte de crescimento destas aglomerações, a velocidade de sua expansão demográfica, as suas características de baixo ordenamento territorial - indistinguível de aspectos acentuados de pobreza - e os efeitos negativos derivados da concentração de relevantes parques industriais levaram a uma série de problemas bastante característicos aos recursos hídricos. Peixinho (2010) também afirma que tais problemas estão relacionados com o crescimento demográfico brasileiro, ainda associado às mudanças no perfil da economia do país e que se refletiu de forma significativa no uso dos recursos hídricos na segunda metade do século.

A falta de uma gestão consolidada traz tais problemáticas, que acarretam em contaminações agudas dos cursos d'água, ampliação de ocorrências de cheias de maiores dimensões, que caracterizam limitações da macrodrenagem e cheias localizadas devido a falhas de microdrenagem, problemas com erosão, deslizamentos e áreas de alagamento, pressão crescente sobre os recursos hídricos e a dificuldade de preservação dos mananciais, como em rios metropolitanos que recebem altas cargas poluentes. Todas estas são adversidades tratadas pela
Política Nacional de Recursos Hídricos (Lei n ${ }^{\circ}$ 9.433/97) como eventos hidrológicos críticos e, para Mendonça e Leitão (2008), são os riscos e vulnerabilidades sociais e ambientais do meio urbano.

As contaminações têm suas causas no fraco ou ausente sistema de infraestrutura sanitária ou por lançamentos industriais irregulares. Já as situações de erosão, deslizamentos e alagamentos ocorrem devido ao avanço urbano sobre áreas indevidas, caracterizadas por um baixo padrão de renda, retornando ao problema citado da falta de saneamento. As inundações ocorrem devido à alta impermeabilização do solo decorrente da urbanização e à velocidade de concentração das águas de chuvas.

O crescimento demográfico, segundo Moreno (2007) e outros autores, ocasiona o aumento na demanda por água e, assim, aumenta a pressão sobre os recursos hídricos para abastecimento público e dificulta a proteção dos mananciais. Este avassalamento traz problemas na captação de água pela diminuição da disponibilidade, dificuldades no tratamento e poluições doméstica, industrial e agrícola, que acarretam em problemas na qualidade da água (Guivant \& Jacobi, 2003).

A problemática detalhada ocorre no território e é neste que se deve instalar uma gestão eficiente a fim de se prover o planejamento adequado do crescimento urbano e o correto manejo dos recursos hídricos. É por meio da gestão territorial que se pode organizar então uma sociedade e seus recursos naturais, base da sustentação de sua economia, e os impactos pelo tipo e grau de desenvolvimento adotado. Existe, portanto, um nexo entre os meios econômicos e físicos que faz retomar a tríade água, território e energia, também base fundamental para o desenvolvimento da sociedade.

Um ponto de apoio da gestão territorial são as legislações dos recursos hídricos, que tiveram ponto de início com o estabelecimento do Decreto Federal $n^{\circ}$ 24.643, de 10 de julho de 1934. Conhecido como o Código de Águas, trouxe mudanças nas diretrizes do Brasil, pois migrou o foco do setor agrário para o urbano industrial, tornando imprescindível a viabilização de geração hidrelétrica. Esta liberação ocorreu por meio da remoção de obstáculos legais que restringiam o aproveitamento do potencial hidrelétrico dos corpos hídricos do território. 
Na ampliação da consciência ambiental, instituições envolvidas com recursos hídricos e a comunidade técnico-científica deram continuidade no avanço legislativo e originaram a formulação e a implantação da Lei $n^{\circ} 9.433$ que, em 1997, instituiu a Política Nacional de Recursos Hídricos - PNRH - e o Sistema Nacional de Recursos Hídricos-SINGREH. A lei estabelece em suas diretrizes a integração da gestão dos recursos hídricos com a gestão ambiental, costeira e estuarina e gestão dos solos. Ademais, ainda inclui os planejamentos setoriais, regionais, estaduais e nacional relacionados com a gestão das águas.

Ainda em seus artigos 25 a 27, a PNRH apresenta definições do Sistema de Informações sobre Recursos Hídricos, citando-o como um sistema de coleta, tratamento, armazenamento e recuperação de informações sobre recursos hídricos e fatores intervenientes em sua gestão. Por meio deste sistema, é pretendido descentralizar a obtenção e a produção de dados e promover o acesso garantido às informações a toda a sociedade. Desta forma, pode-se reunir, firmar e divulgar os dados e informações sobre a situação qualitativa e quantitativa dos recursos hídricos no Brasil com atualização permanente. As diretrizes apresentadas pela Lei acerca do sistema conduzem ao estilo necessário da ferramenta, que é produto do caso a ser apresentado a seguir neste trabalho.

\subsection{Sistema de Informação Geográfica como apoio à gestão territorial}

Para Paredes (1994), os trabalhos de planejamento e gerenciamento dos recursos naturais requerem dados como uso do solo, tipos de solos, superfícies de água e hidrografia, vegetação, entre outros importantes. Para cada adversidade, gera-se um cenário desenvolvido com o propósito de identificar dados quantitativos para o planejamento e a tomada de decisão. Desta forma, se conduz a avaliação dos recursos e a análise da situação, de modo a organizar informações para o planejamento (Donha et al., 2006). Segundo Maximiniano (1996), os Sistemas de Informações Geográficas - SIG - auxiliam na análise integrada dos dados do meio físico, sendo utilizado por diversos atores que tratam da questão ambiental como importante ferramenta para o planejamento.
Moreno (2007) qualifica como relevante a utilização de métodos de geoprocessamento em projetos, pois facilitam a consulta à base de dados e permitem a visualização dos resultados por meio de mapas temáticos. O autor completa dizendo que os SIG proporcionam uma melhor compreensão do espaço e permitem a identificação de padrões, perfis sociodemográficos e eixos de crescimento regional, fundamentais para o processo de planejamento.

Entretanto, a implementação de SIG em organizações pode encontrar obstáculos perante seu modelo inovador de trabalho ainda não disseminado. Por vezes, o estabelecimento de sistemas informatizados pode gerar impactos socioculturais na equipe em virtude da difícil adequação dos utilizadores aos novos métodos e processos de trabalho e fluxos de informações (Hypolito \& Pamplona, 2000). Em experiência de implantação de SIG com três empresas, os autores citados concluíram que as principais dificuldades encontradas foram: adequação dos processos ao software; queixas devido à pouca experiência da equipe; falta de comprometimento em todos os níveis hierárquicos; resistência das pessoas às mudanças impostas pela implantação; e falta de aplicação e integração do SIG pelos mesmos. Estas resumem as dificuldades institucionais que envolvem, comumente, barreiras humanas provindas da falta de conhecimento e capacitação, desinformação tecnológica, insciência no uso de microcomputadores, entre outros motivos culturais e sociais.

Entre as dificuldades apresentadas, há também os empecilhos técnicos durante a implantação e operação dos SIG. Alguns exemplos são as dificuldades na obtenção de informações digitais que, em muitos casos, são inexistentes, não estão atualizadas ou são financeiramente inacessíveis; o software não atender aos requisitos básicos requeridos; recursos insuficientes; barreiras departamentais à troca de dados; contexto técnico desajustado; ausência de equipe de suporte; e também problemas de cunho tecnológico e de hardware (Silva, 2011).

Pierantoni e Viana (2003) realizaram estudo de implantação e previram que o entendimento das dificuldades e benefícios durante implantação de um SIG corporativo, por meio de questionários e entrevistas, pode auxiliar na aceitação dos sistemas informatizados. 
Ponderando todos os benefícios e empecilhos é que deve ser planejada a implementação de um SIG, demonstrando a necessidade de fundamentação e compreensão a fim de que se obtenha êxito no uso dos Sistemas de Informações Geográficas.

Tais ferramentas são definidas como sistemas de informações robustos, ou seja, arquitetados de maneira a possibilitar seu uso e manuseio, por meio da internet (web) e com grande interatividade com o usuário. Por isso, viabilizam o cruzamento de informações para análises e simulações de dados, geração de mapas e relatórios detalhados, integrando as informações descritivas com suas respectivas localizações geográficas. Estas são as características principais das tecnologias desenvolvidas, tratando a informação de maneira conjunta, georreferenciada e auxiliando os processos de tomada de decisão.

\subsection{Utilização de ferramentas livres para desenvolvimento de Sistemas de Informações Geográficas}

O tema software livre é muito discutido entre os diferentes profissionais, tanto da área da Tecnologia da Informação quanto de outras áreas que utilizam a tecnologia de forma direta e indireta em suas aplicações. Segundo Bley Jr. (2006), o software livre de código aberto oferece alternativas para o uso universal de tecnologias, mas é cercado muitas vezes por preconceitos relacionados com a baixa credibilidade em matéria de segurança da informação.

O emprego de softwares livres de código aberto tem crescido por desempenhar satisfatoriamente as atividades e também por diminuir os encargos de licenças, ofertando independência das empresas proprietárias (Sargento, 2004). Sua utilização também é vista para o desenvolvimento de Sistemas de Informações Geográficas - SIG, onde as ferramentas livres de código aberto abrangem e executam as atividades necessárias para o desenvolvimento destes.

Ponderando as informações apresentadas, o desenvolvimento de sistemas e aplicações utilizando software livre possibilita ao usuário, em diferentes níveis da sociedade, gerir e tomar decisões a respeito do território de modo eficiente e assertivo. Ademais, oportuniza a ágil produção de informações intermediárias e finais, além da inserção de itens anteriormente não analisados devido às novas interações possíveis em qualquer cenário (Donha et al., 2006).

Neste contexto, o CIH considera que a tríade água, energia e tecnologia está associada à premissa de que, para o desenvolvimento sustentável de uma região ou país, são necessárias ferramentas e tecnologias de gestão territorial livres a fim de que se facilite o planejamento e a execução de políticas públicas sistêmicas. Como em qualquer âmbito social, o desenvolvimento sustentável é uma necessidade, independente do poder aquisitivo ou desenvolvimento tecnológico, partindo da premissa de que essas tecnologias não possuam custos elevados, sejam flexíveis, de fácil manuseio e tenham acessibilidade.

\section{Metodologia de gestão}

O Centro Internacional de Hidroinformática - CIH - é um centro de Categoria II da UNESCO, resultado da parceria entre a Itaipu Binacional e o Programa Hidrológico Internacional (PHI-UNESCO). Referência em hidroinformática aplicada à gestão dos recursos hídricos, o CIH trabalha a gestão territorial com tecnologias livres de geoprocessamento e SIG, tratando a temática água e energia por meio de uma perspectiva ampla. Desenvolvendo e disponibilizando sistemas em ambiente web, o Centro realiza o registro de informação em bases de dados geográficas e os apresenta em mapas interativos por meio desses sistemas.

A metodologia utilizada pelo CIH para estruturação e inter-relação dos dados e informações geradas pelos instrumentos de gestão territorial/ambiental é baseada no método do Cadastro Técnico Multifinalitário - CTM. Informações técnicas cadastrais permitem definir espacialmente o território e caracterizar seus aspectos ambientais e, por isso, são imprescindíveis na prática de gestão e definições das melhores políticas de desenvolvimento e planejamento (Bley Jr., 2006).

O CIH ainda oferece oficinas de gestão territorial, onde se estabelece uma relação direta de uso das tecnologias de geoprocessamento com a análise do território, orientada principalmente ao diagnóstico e manejo da bacia hidrográfica nas áreas de gestão ambiental e pros- 
pecção de fontes de energias renováveis a fim de que seus futuros utilizadores compreendam a ferramenta e a apliquem com eficiência.

No caso do desenvolvimento de sistemas no CIH, utilizam-se tecnologias livres de soluções já existentes e consolidadas. Dentre elas, podem-se citar algumas principais: PostgreSQL com PostGIS (banco de dados com extensão geográfica), JavaServer Faces (conjunto de funcionalidades para aplicações Java na web), OpenLayers (biblioteca para visualização e manipulação de mapas), GeoTools (biblioteca desenvolvida em Java para manipulação de dados geográficos) e Geoserver (servidor de mapas web).

Ressalta-se que os sistemas desenvolvidos pelo CIH compreendem um público diversificado, que envolve comunidades com graus variados de capacidade para gerir os softwares. Na sequência, relata-se um case que apresenta algumas ferramentas de suporte à decisão desenvolvidas pelo CIH, que contribuem na gestão do território pelos diversos atores envolvidos, de acordo com a sua finalidade.

\subsection{Apresentação de um case: a Bacia \\ Hidrográfica do São Francisco Verdadeiro}

Uma área de importância para a Itaipu Binacional é a sub-bacia do Rio São Francisco Verdadeiro (SFV), inserida na Bacia Hidrográfica Paraná 3, como confere-se na Figura 4. A sub-bacia tem sua foz no reservatório da Usina, contendo a área de drenagem mais extensa e representativa na bacia incremental da hidroelétrica, por isso, possui relevante influência na qualidade da água do lago. Esta sub-bacia também pertence ao Programa HELP Hydrology for the Environment, Life and Policy - da UNESCO, uma iniciativa que fomenta o gerenciamento de bacias hidrográficas em todo o mundo de acordo com critérios sustentáveis. A sub-bacia do Rio São Francisco Verdadeiro foi a primeira bacia brasileira e a quinta latino-americana a ser incluída no $\operatorname{HELP}(\mathrm{CIH}, 2013)$.

A bacia SFV possui uma área de $2.219,1 \mathrm{~km}^{2}$, abrangendo 11 (onze) municípios de economia essencialmente agropecuária no Oeste do Estado do Paraná - Brasil e compreende uma população de 262.778 habi-

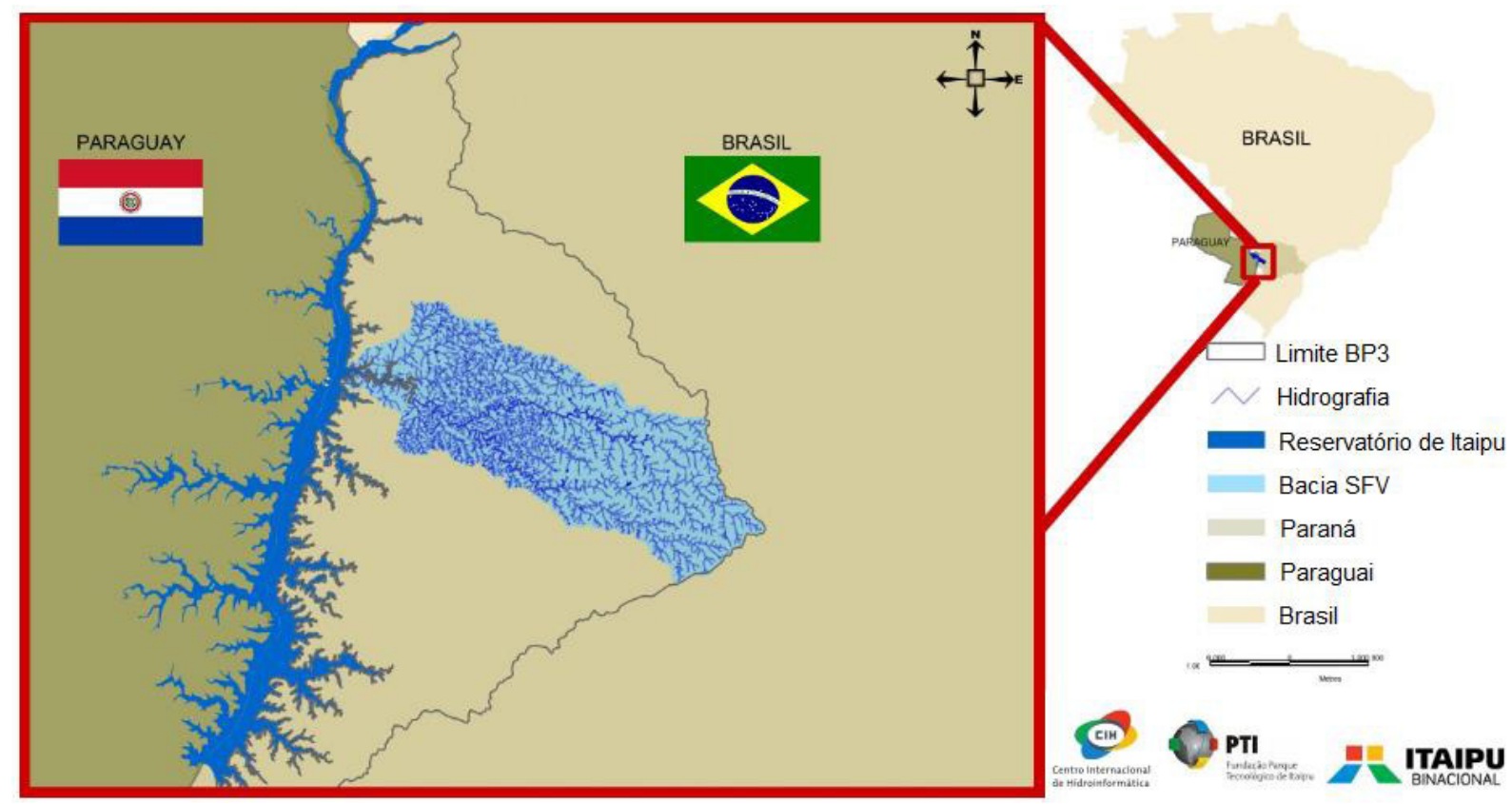

FIGURA 4 - Mapa de localização da Bacia Hidrográfica do São Francisco Verdadeiro.

FONTE: Centro Internacional de Hidroinformática, 2013. 
tantes. O rio São Francisco Verdadeiro percorre $240 \mathrm{~km}$ no seu canal principal e sua rede hidrográfica percorre aproximadamente $3.280 \mathrm{~km}$ até encontrar o reservatório.

Esta região é especializada na cadeia produtiva do plantio de soja e milho e na industrialização de carne suína e avícola, além da intensa produção de gado leiteiro. Essas são atividades de alto impacto ambiental, pois geram efluentes que podem degradar a qualidade do rio e do reservatório de Itaipu, tornando o ambiente debilitado. Por meio da análise das atividades decorrentes no território da bacia, constatou-se a necessidade de mudança no modo de compreender e abordar seu desenvolvimento e como este intensifica os efeitos sobre o meio ambiente.

$\mathrm{O}$ desafio de estabelecer o nexo água e energia como elementos integrados e diretamente relacionados, tratando-os de maneira conjunta, a fim de gerar soluções que compatibilizem esta importante antinomia, são de extrema importância para o desenvolvimento desta região. Os resíduos gerados por meio das atividades agropecuárias na bacia hidrográfica SFV, poluentes do solo e água, se tratados de maneira correta, podem ser transformados em energia a partir da conversão e uso do biogás como fonte energética.

Considerando esse fato, pode-se citar o projeto-piloto nomeado de Condomínio de Agroenergia para Agricultura Familiar do rio Ajuricaba, que faz o aproveitamento agroenergético do biogás gerado pelos dejetos, transformando-o em energia térmica e elétrica. O rio Ajuricaba é uma pequena microbacia pertencente à bacia do SFV, com 33 produtores pecuaristas que possuem biodigestores para degradação dos dejetos suínos e bovinos. As propriedades estão conectadas por um gasoduto que conduz o biogás gerado pelos biodigestores até uma Central Termoelétrica, com potencial de produção de aproximadamente $1.460 \mathrm{kWh} /$ dia.

Um prévio estudo de potencial de produção energética de biomassa residual da produção animal na bacia São Francisco Verdadeiro, realizado pelo Centro Internacional de Hidroinformática, é apresentado na Figura 5, onde foi estimado o potencial de produção de biogás a partir de dados de plantéis na bacia e, posteriormente, o potencial de produção energética, considerando fatores de conversão específicos utilizados pelas normas do IPCC (2006) Guidelines for National Greenhouse Gas Inventories.
Segundo as informações disponibilizadas no mapa, pode-se prever a concepção de arranjos para o aproveitamento energético por biogás potencial nessa região. A utilização de fontes energéticas que conciliem a preservação do ambiente e a valorização de uma economia em torno deste modelo representa o objetivo deste trabalho, onde, por meio da utilização dos dejetos animais como matéria-prima na geração de energia, relacionam-se as temáticas água e energia com a gestão territorial visando à preservação do meio ambiente.

\subsection{Sistemas de Informação Geográfica de Biogás - SIGBiogás}

O Sistema de Informações Geográficas do Biogás é uma tecnologia web que permite o cadastramento e a localização de unidades de produção agropecuária com o objetivo de analisar o potencial de geração de biogás a partir das diferentes biomassas disponíveis nas atividades agropecuárias. O sistema possui algoritmos matemáticos que possibilitam a simulação de produção do biogás, por meio da entrada de dados básicos dos plantéis. O resultado da estimativa é uma avaliação da unidade produtiva do ponto de vista de produção de biogás e energia, além de sua viabilidade de implantação. O sistema ainda permite que o usuário visualize em mapas interativos a localização geográfica das unidades produtivas, propiciando estudos de arranjos técnicos do melhor aproveitamento do potencial no território de interesse. Além disso, cria-se um banco de dados com informações potenciais para constituir novas pesquisas e projetos relacionados com a temática água e energia.

\section{- Sistema Monitoramento Participativo da Qualidade da Água de Rios}

Em 2006, o Programa HELP da UNESCO, o Programa ESPOL VLIR (Consejo Nacional de Universidades Flamencas) e a Itaipu Binacional promoveram o "Curso Internacional de Monitoramento Biológico" na cidade de Foz do Iguaçu. O curso objetivou fortalecer a região com profissionais capacitados na identificação e na utilização desta metodologia, atuando como difusores deste conhecimento aplicado para benefício ambiental dos ecossistemas da região. 


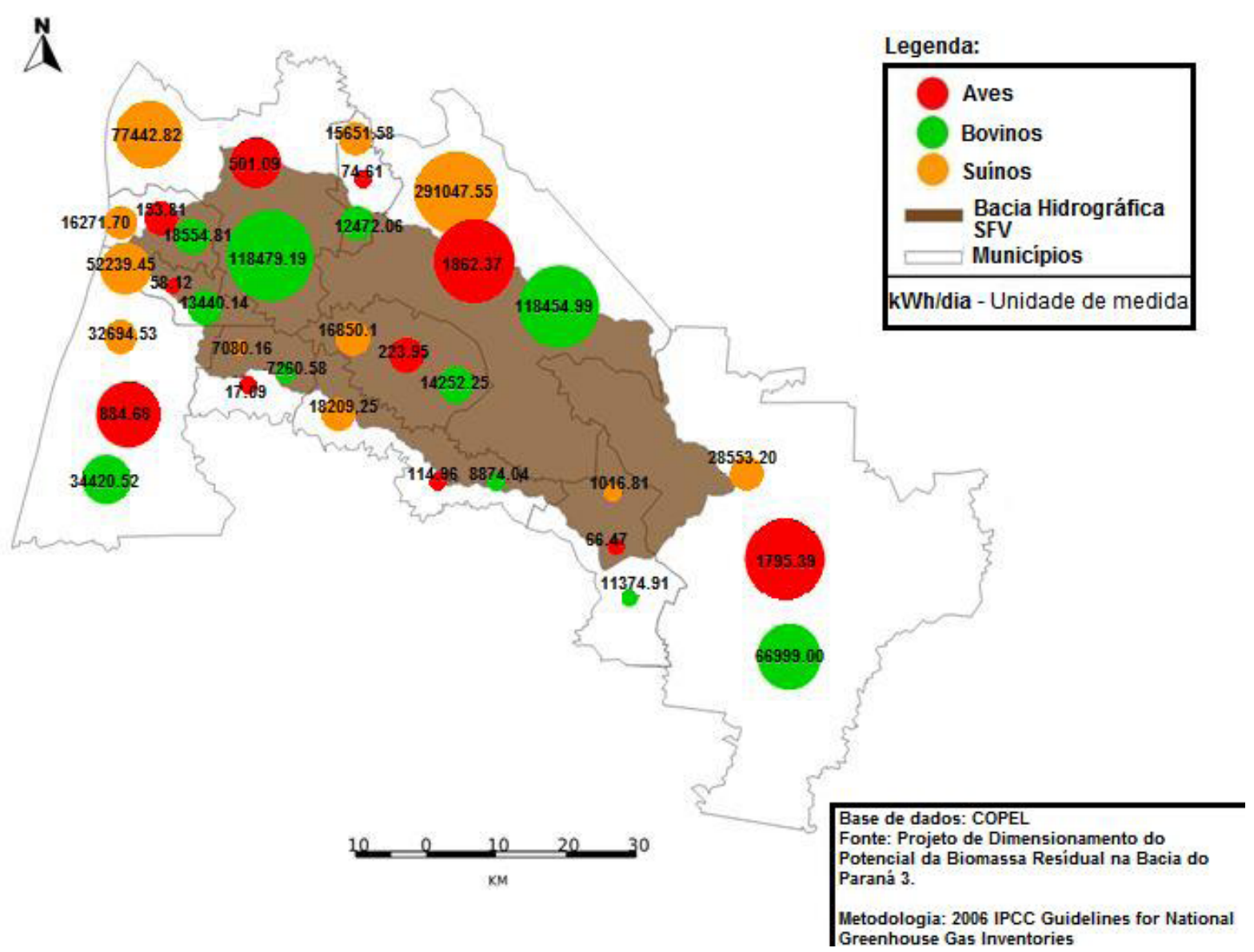

FIGURA 5 - Potencial de produção de energia a partir do biogás oriundo de dejetos animais.

FONTE: Centro Internacional de Hidroinformática, 2013.

Em parceria com a FIOCRUZ, foi desenvolvido o "Programa Participativo de Avaliação Integrada da Qualidade da Água", utilizando metodologias simples, eficientes como instrumentos de avaliação e participativas. Isto porque incentiva a atuação das comunidades regionais, segmento social mais diretamente atingido, com maior possibilidade de atuação no controle da qualidade das águas e que deve estar presente nos processos decisórios sobre o uso e conservação dos rios.
Inicialmente, o projeto foi desenvolvido em rios da bacia do Rio São Francisco Verdadeiro. Resultados importantes, tanto de monitoramento de rios como de Pesquisa - Ação - Participante (PAP) foram gerados, norteando a implantação de novos projetos. Para o melhor gerenciamento dos resultados, o CIH criou o Sistema Monitoramento Participativo da Qualidade da Água de Rios (link: < hidroinformatica.org/mp >), com cadastro e visualização das informações via internet. 


\section{SIGBIOGÁS}

Sistema de Informações

Geográficas do Biogás

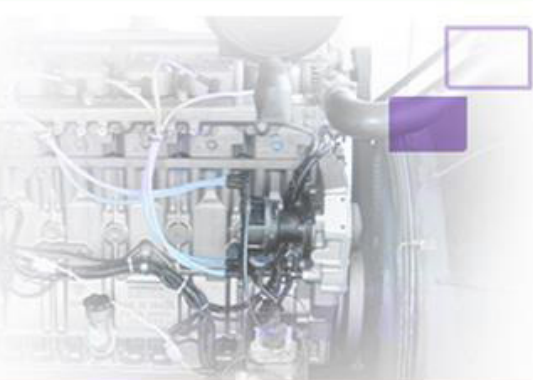

Mapa Interativo $~$ Meu Perfil

Página Inicial

Usuários * Cadastros -

Consultas e Relatórios

Sair

Visualização dos pontos das Unidade Produtiva cadastradas
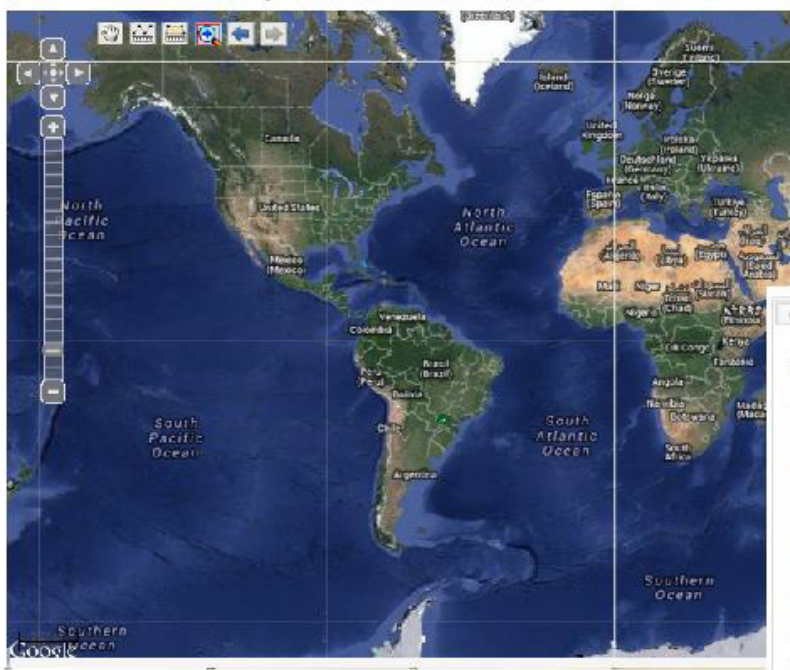

FIGURA 6 - Captura de tela do Sistema SIGBiogás.

FONTE: Centro Internacional de Hidroinformática, 2013.

O sistema consiste no armazenamento web dos dados de monitoramento de rios levantados pelas comunidades participantes, permitindo a sua livre visualização geográfica, incentivando a disseminação do conhecimento dos dados gerados, mobilizando a população quanto às questões socioambientais e à tomada de decisões para melhoria da condição ambiental da região, de forma a subsidiar o uso sustentável da água e dos solos em toda a região.
Página Inicial - Acessos Rápidos

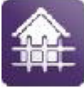

$\underset{\substack{\text { Unicod } \\ \text { Trod tivas }}}{ }$

Principais Consultas e Relatórios
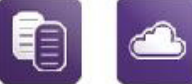

Histilicudt

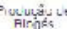

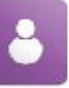

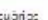

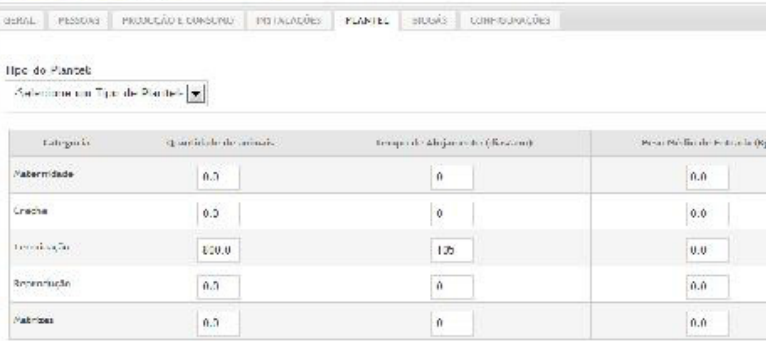

ane vorrecto

As informações geradas podem ser utilizadas pelos respectivos Comitês de Bacia, auxiliando na elaboração do Plano de Gerenciamento, dando suporte à tomada de decisões do território e quanto aos padrões de qualidade das águas compatíveis com os usos a que forem destinadas, conforme pressupõe a resolução 357/05 do CONAMA, subsidiando o processo de concessão de outorga de direitos de uso e cobrança dos recursos hídricos. 


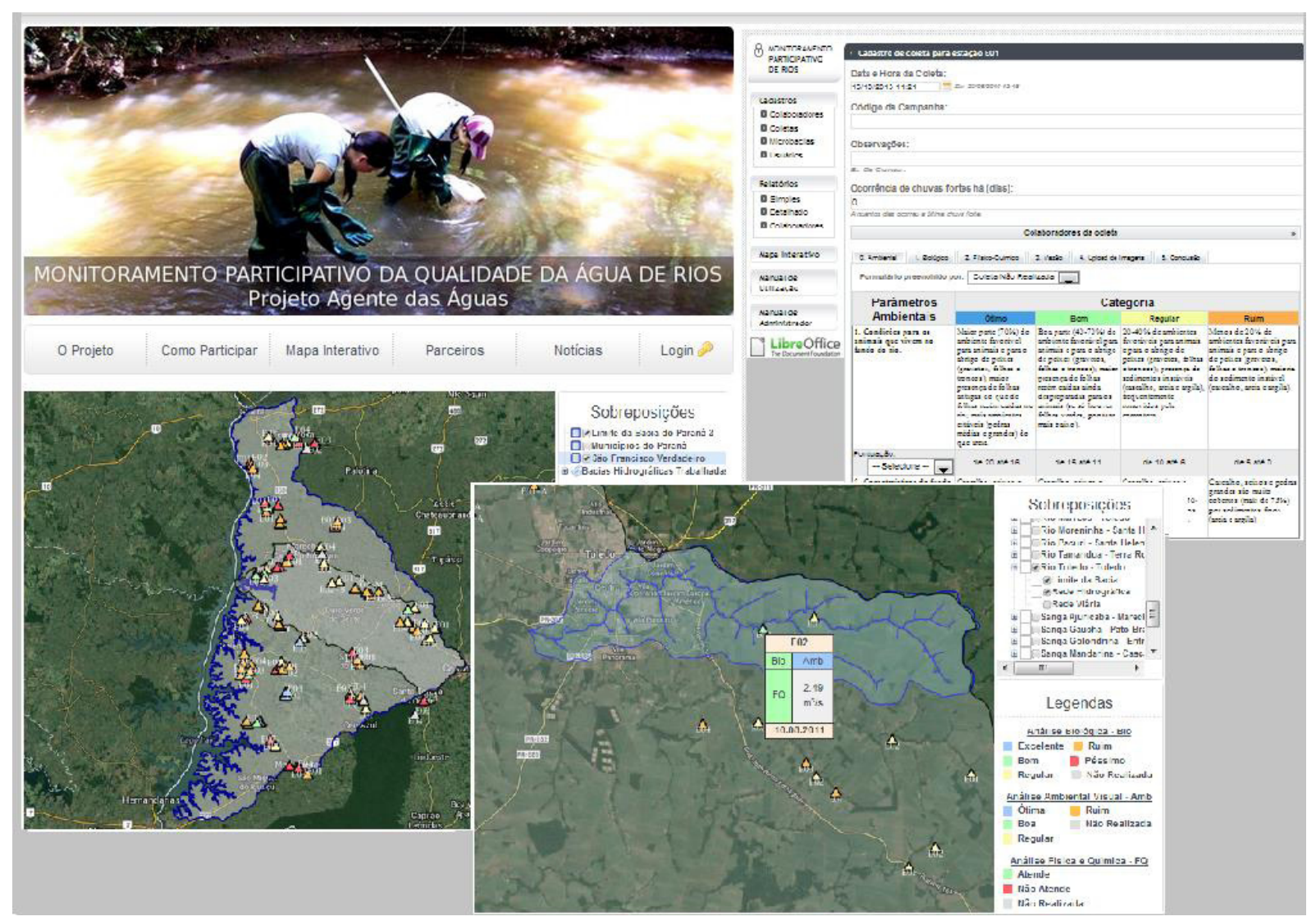

FIGURA 7 - Capturas de tela do Sistema de Monitoramento Participativo de Rios.

FONTE: Centro Internacional de Hidroinformática, 2013.

- Sistema de Gestão das Bacias HELP(Hydrology for the Environment, Life and Policy)

Aprovado pelo Programa Hidrológico Internacional (PHI) da UNESCO, o Programa HELP traz uma nova abordagem para a gestão integrada de bacias hidrográficas proposta por um quadro de especialistas em políticas públicas e de legislação sobre a água, gestores de recursos hídricos e cientistas. O HELP atua em sua rede global de bacias interligadas visando melhoras nas relações entre a hidrologia e as necessidades da sociedade, trabalhando em cinco temas: Água e Clima; Água e Alimento; Qualidade da Água e Saúde humana; Água e Ambiente; e Água e Conflitos.
O HELP traz, como instrumento para solucionar problemas ambientais, uma abordagem integrada que envolve engenharia ambiental, processo de hidrologia, política ambiental, direito e economia e gestão ambiental, onde se incorpora a gestão territorial. Ainda fornece informações que permitem aos decisores políticos enfrentar os problemas decorrentes dos conflitos de usos local, regional e internacional, prevendo uma distribuição sustentável dos recursos hídricos.

O objetivo do Sistema HELP (Figura 8) é reunir informações de cunho econômico, social e ambiental, para a visualização facilitada da situação da bacia e posterior direcionamento de ações para a gestão da 


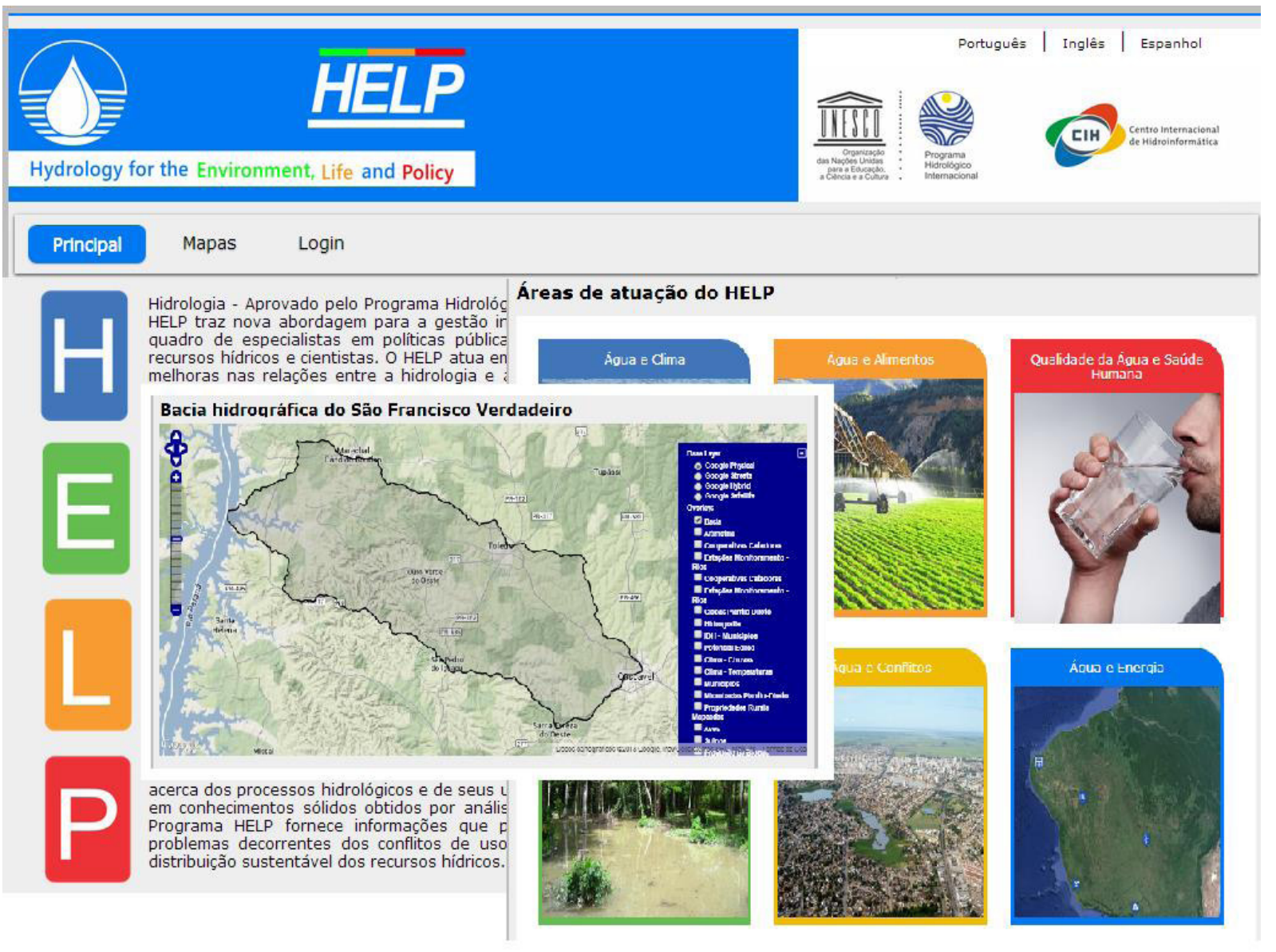

FIGURA 8 - Captura de tela do Sistema Bacias HELP.

FONTE: Centro Internacional de Hidroinformática, 2013.

mesma perante as deficiências identificadas. Além disso, a visualização geográfica desses locais possibilita a identificação da presença de impactos ambientais e a relação desse dado com as informações sociais e econômicas, direcionando o desenvolvimento de políticas públicas efetivas para solucionar essas problemáticas constatadas. Por envolver diversas bacias, a utilização da ferramenta implica o envolvimento de atores sociais, como comitês de bacias, prefeituras, órgãos ambientais, entre outros, na gestão dessas informações, oportunizando a troca de experiências de ações que podem ser replicadas em diferentes cenários.
- Web Rádio Água - Modelo de comunicação entre atores na bacia hidrográfica HELP São Francisco Verdadeiro

A Web Rádio Água - WRA é um projeto desenvolvido pelo Centro Internacional de Hidroinformática e conta com a parceria da Assessoria de Energias Renováveis - ER.GB - da Itaipu Binacional, da Fundação Parque Tecnológico Itaipu - FPTI - e do Programa Hidrológico Internacional - PHI - da UNESCO. Por meio da mediação pedagógica e aprendizagem colaborativa, objetiva-se o trabalho com diferentes linguagens midiáticas, com ênfase em arquivos de áudio, reunindo 
esforços e interatividade para gerir conhecimento educativo e fomentar a sociedade civil para a construção da cidadania e promoção da sustentabilidade.

O projeto aborda a comunicação visando ao bem comum, por meio de uma plataforma web na qual os usuários têm um espaço para interagir, produzir e publicar seus conteúdos de interesse comum, proporcionando o intercâmbio de conhecimento, a construção da cidadania e a promoção da sustentabilidade a partir da participação e colaboração da sociedade. Desta maneira, incentiva-se um modelo de comunicação entre os atores que interagem na bacia hidrográfica São Francisco Verdadeiro disponibilizando a plataforma WRA como meio para tal comunicação e troca de informações a respeito de seus ambientes.

\section{Conclusões}

O consumo excessivo dos recursos naturais aproxima-os do esgotamento, da poluição e do aumento global em seus preços. Por isso, são necessárias atitudes de prevenção da escassez e da poluição da água e a criação de tecnologias que ajudem a população a enfrentar as mudanças das matrizes energéticas. É primordial,

\section{Referências}

ANA - Agência Nacional das Águas. Conjuntura dos recursos hídricos no Brasil: informe 2012. Ed. Especial. Brasília, 2012. $215 \mathrm{p}$.

ANP - Agência Nacional de Petróleo. Importações e exportações. Disponível em: <http://www.anp.gov.br/?dw=8475>. Acesso em: out. 2013.

Berndes, G. Bioenergia e água - implicações da produção em larga escala de bioenergia para o uso e suprimento de água. Global Environmental Change, 12(4), 253-271, 2002.

Bley Jr., C. J. Cadastro técnico multifinalitário, uma ferramenta gerencial para a integração de critérios de gestão territorial e gestão ambiental: o caso da Itaipu Binacional. Florianópolis - UFSC, 2006. $160 \mathrm{f}$.

; Libânio, J. C.; Galinkin, M.; Oliveira, M. M. Agroenergia da biomassa residual: perspectivas energéticas, portanto, promover soluções e ferramentas para conciliar esse importante nexo entre água e energia, envolvendo conhecimentos gerais e específicos, tecnologia e política, considerando aspectos sociais e econômicos.

Atividades detalhadas de caracterização do uso da água em microbacias e a sistematização de informações trazem benefícios ao meio ambiente, preservando os cursos d'água, divulgando medidas agroecológicas, minimizando impactos nos solos e recursos hídricos, além de propiciar o acompanhamento da qualidade da água. Tais benefícios são propiciados pela gestão territorial abrangente de diversos setores que, associada às geotecnologias, organiza seus dados e gera informações essenciais para o manejo adequado da água.

Diante deste cenário, o $\mathrm{CIH}$ desenvolve diversos projetos relacionados com a investigação do potencial de fontes de energias renováveis no território, avaliando o melhor aproveitamento da matriz energética existente. Para a execução de projetos com esta visão, deve-se realizar uma consistente gestão territorial aplicada à água e à energia, por meio de etapas que englobem trabalhos de investigação territorial. A consolidação destes projetos permite sua prospecção para replicação em diferentes cenários.

socioeconômicas e ambientais. Foz do Iguaçu/Brasília: Technopolitik Editora, 2009.

Brasil. Lei ${ }^{\circ} 9.433$ de 08 de Janeiro de 1997. Institui a Política Nacional de Recursos Hídricos, cria o Sistema Nacional de Gerenciamento de Recursos Hídricos, regulamenta o inciso XIX do art 21.

Bronzatti, F. L.; Iarozinski Neto, A. Matrizes energéticas no Brasil: Cenário 2010-2030. In: Anais do XXVIII Encontro Nacional de Engenharia de Produção. Rio de Janeiro, 2008.

Buss, D. F.; Oliveira, R. B.; Baptista, D. F. Monitoramento biológico de ecossistemas aquáticos continentais. Oecologia Brasiliensis, 12(3), 1, 2008.

CEMIG - Companhia Energética de Minas Gerais. Estudo de Otimização Energética. Belo Horizonte, 1993. 
CIH - Centro Internacional de Hidroinformática. Disponível em: <http://hidroinformatica.org/>. Acesso em: out. 2013.

. Monitoramento Participativo de Rios - MP. Disponível em: <http://hidroinformatica.org/MP>. Acesso em: out. 2013.

. Sistema de Informações Geográficas de Biogas SIGBiogás. Disponível em: <http://hidroinformatica.org/ sigbiogas $>$. Acesso em: out. 2013.

. Sistema Bacias HELP. Disponível em: $<$ http://hidroinformatica.org/baciashelp $>$. Acesso em: out. 2013.

CONAMA - Conselho Nacional do Meio Ambiente. Resolução n. ${ }^{\circ}$ 357, de 17 de março de 2005. Brasília: DOU de 18/03/2005.

Donha, A. G.; Souza, L. C. de P.; M. L. Sugamosto. Determinação da fragilidade ambiental utilizando técnicas de suporte à decisão e SIG. Revista Brasileira de Engenharia Agrícola e Ambiental, 10(1), 175-181, 2006.

Goldemberg, J.; Lucon, O. Energia e meio ambiente no Brasil. Estudos Avançados, 21(59), 7-20, 2007.

Gregório, V.; Martins, M. Q. Água e energia - Conexões para uma nova sustentabilidade. In: Anais do VIII Congresso Nacional de Geografia. Lisboa, 2011.

Guivant, J. S.; Jacobi, P. R. Da hidrotécnica à hidropolítica: novos rumos para a regulação e gestão dos riscos ambientais no Brasil. Cadernos de Pesquisa Interdisciplinar em Ciências Humanas, 4(43), 2-26, 2003.

Hypolito, C. M.; Pamplona, E. Principais problemas na implantação de um sistema integrado de gestão. In: Anais do Encontro Nacional de Engenharia de Produção, 20, São Paulo, 2000.

IBGE - Instituto Brasileiro de Geografia e Estatística. Pesquisa Nacional de Saneamento Básico, 2008. Rio de Janeiro: IBGE, 2010.

IPCC - Intergovernmental Panel on Climate Change. Diretrizes para inventários nacionais de gases de efeito estufa. Japão: IGES, 2006.

Itaipu Binacional - Programas Cultivando Água Boa/Porã e Plataforma Itaipu de Energias Renováveis. Acesso em: out. 2013.

LEAL, M. S. Gestão ambiental de recursos hídricos: princípios e aplicações. Rio de Janeiro: CPRM, 1998.

Lima, J. E. F. W.; Ferreira, R. S. A.; Christofidis, D. O uso da irrigação no Brasil: o estado das águas no Brasil. Brasília: Agência Nacional de Energia Elétrica, 1999. Disponível em: $<$ http://cnptia.embrapa.br/>. Acesso em: out. 2013.
Marouelli, W. A.; Silva, W. L. C. Seleção de sistemas de irrigação para hortaliças. Brasília: Embrapa. 1998.

Martins, R. A.; Vaz, J. C. A.; Caldas, E. L. Gestão do desenvolvimento local no Brasil. Revista de Administração Pública, Rio de Janeiro, 44(3), 559-590, 2010.

Maximiniano, G. A. Bacia do Rio Pato Branco: ensaio cartográfico para análise da fragilidade do meio físico com uso de geoprocessamento. São Paulo, Dissertação (Mestrado em Geografia e Física) - USP, 1996.

Mendonça, F. A.; Leitão, S. A. M. Riscos e vulnerabilidade socioambiental urbana: uma perspectiva a partir dos recursos hídricos. GeoTextos, 4(1-2), 145-163, 2008.

MME - Ministério das Minas e Energia. Balanço Energético Nacional - BEN, 2012. Disponível em: $<$ https://ben.epe.gov. br/>. Acesso em: out. 2013.

. Balanço Energético Nacional - BEN, 2013. Disponível em: <https://ben.epe.gov.br/>. Acesso em: out. 2013.

. O PROINFA. Disponível em: $<$ http://www.mme.gov. br/programas/proinfa/>. Acesso em: out. 2013.

Moreno, J. Bacia Hidrográfica: convergência de investigação científica e Unidade de Gestão Territorial - A contribuição do geoprocessamento. Piracicaba, Projeto de Pesquisa (Relatório Científico) - FAPESP, 2007.

Moura, G. N. P. A relação entre água e energia: gestão energética nos sistemas de abastecimento de água das companhias de saneamento básico do Brasil. Rio de Janeiro, Dissertação (Mestrado em Planejamento Energético) - UFRJ, 2010.

Paredes, E. A. Sistema de Informação Geográfica: (geoprocessamento) princípios e aplicações. São Paulo: Érica Ltda., 1994. $690 \mathrm{p}$.

Peixinho, F. C. Gestão sustentável dos recursos hídricos. In: Anais do XVI Congresso Brasileiro de Águas Subterrâneas. São Luís, MA, 2010.

Pierantoni, C. R.; Viana, A. L. Avaliação de processo na implementação de políticas públicas: a implantação do Sistema de Informação e Gestão de Recursos Humanos em Saúde (SIG-RHS) no contexto das reformas setoriais. Physis: Revista de Saúde Coletiva, 13(1), 59-92, 2003.

Rauber, D.; Oliveira, F. A. C. Uma contextualização da demanda de água na indústria. Synergismus Scyentifica UTFPR, 3(1), 2008.

Rio Carrillo, A. M.; Frei, C. Water: a key resource in energy production. Energy Policy, v. 37, n. 11, p. 4303-4312, 2009. 
Santos, B. S.; Garavito, C. A. R. Introduction: expanding the economic canon and searching for alternatives to neoliberal globalization. In: sible. Londres: Verso, 2006. (Org.). Another production is pos-

Sargento, C. SIG atingem a maturidade. Semana Informática, 685, 2004.

Silva, A. J. F. Implementação de um sistema de informação geográfica numa autarquia utilizando software livre e de código aberto. Lisboa, 2011.
Silveira, G. D.; Silva, C. E.; Irion, C. A. O.; Cruz, I.; Retz, E. F. Balanço de cargas poluidoras pelo monitoramento quali-quantitativo dos recursos hídricos em pequena bacia hidrográfica. Revista Brasileira de Recursos Hídricos, 8(1), 5-11, 2003.

WBCSD - World Business for Sustainable Development. Water, Energy and Climate Change: A contribution from the business community. 2009. Disponível em: $<\mathrm{http}: / / w w w . w b c s d$. org/>. Acesso em: out. 2013. 